\title{
Wind Power Potential over the World's Deepest River Valley
}

\section{Ram P. Regmi and Sangeeta Maharjan}

Journal of Nepal Physical Society

Volume 4, Issue 1, February 2017

ISSN : 2392-473X

Editors:

Dr. Gopi Chandra Kaphle

Dr. Devendra Adhikari

Mr. Deependra Parajuli

JNPS, 4 (1), 54-59 (2017)

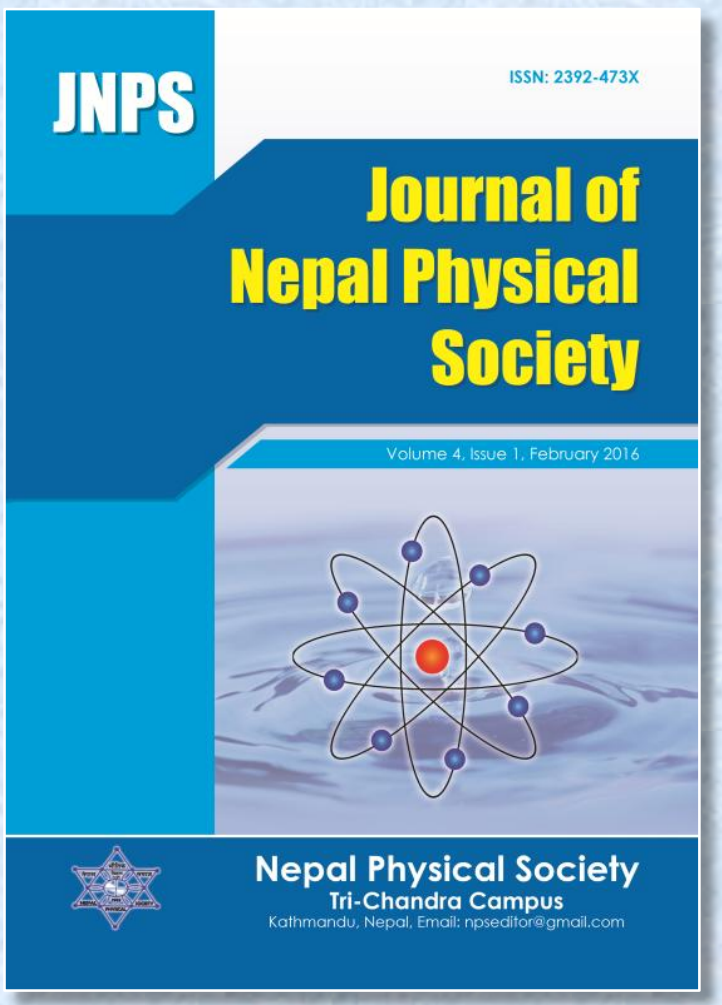

Published by:

Nepal Physical Society

P.O. Box : 2934

Tri-Chandra Campus

Kathmandu, Nepal

Email: npseditor@gmail.com 


\title{
Wind Power Potential over the World's Deepest River Valley
}

\author{
Ram P. Regmi* and Sangeeta Maharjan \\ National Atmospheric Resource and Environmental Research Laboratory (NARERL) \\ Central Department of Physics, Tribhuvan University, Kirtipur, Nepal \\ Corresponding Email: ram.p.regmi@gmail.com
}

\begin{abstract}
Wind power potential prevailing over the world's deepest river gorge, the Kali Gandaki River Valley, located in the western trans-Himalaya region of Nepal, has been assessed and mapped at $1 \mathrm{~km} \times 1 \mathrm{~km}$ horizontal grid resolution with the application of Weather Research and Forecasting (WRF) modeling system. The wind power potential maps cover $70 \mathrm{~km} \times 70 \mathrm{~km}$ area, which encloses the very first and failed wind power project in the country and the Jomsom Airport at the center. The simulated wind characteristics compare well with the available observed wind characteristic. The wind power potential appears to vary from good to outstanding over $200 \mathrm{~km}^{2}$ area along the axis of Kali Gandaki River Valley. However, a detail long-term observation, numerical simulation as well as engineering examinations are desired to address abnormal valley wind characteristics for sustainable power production over the area.
\end{abstract}

Keywords: Wind power potential, Jomsom, Kali Gandaki Valley.

\section{INTRODUCTION}

The Kali Gandaki River Valley, located in the western Trans-Himalaya region of Nepal, is the world's deepest river gorge. The valley extends from middle hills of the Himalaya and exit to the Tibetan Plateau. The axis of the valley orients southeasterly at Ghasa and few kilometers upstream to Lete and then bends taking southwesterly up to
Lo Manthan and beyond. The valley ascends steeply from Ghasa to Lete while it is more gradual from Lete to Lo Manthang. The gorge becomes as much as $5000 \mathrm{~m}$ deep while crossing the Annapurna and Dhaulagiri Himalayas. The Jomsom Airport, one of the most difficult airports in the world, resides at an elevation of $2682 \mathrm{~m}$ above the mean sea level (see figure 1 for locations).
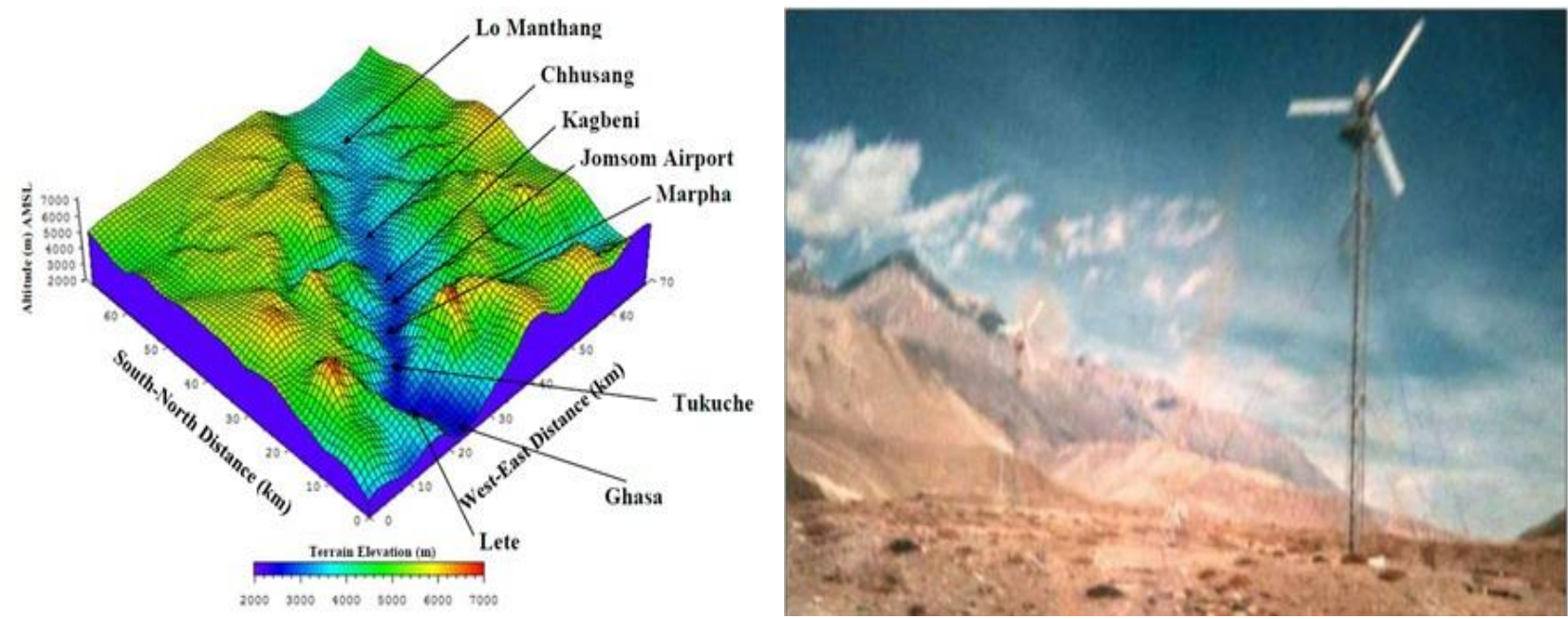

Fig. 1. Bird-Eye view of Kali Gandaki River Valley and its surroundings (left) and the ruins of Nepal's first wind farm photographed by A. Thapa in Kagbeni area of the valley (right). 
The very first $32 \mathrm{~kW}$ wind power project in the country was implemented at Kagbeni in 1992 aiming to provide electricity for the isolated local communities beyond the Himalaya. However, the wind turbines were severely damaged by gusty winds just after two months it came into operation (MOPE, 2003). Not only the Kagbeni wind power project, $12 \mathrm{~kW}$ Nagarkot Wind Farm installed at the hilltop of eastern surrounding mountain ridge of Kathmandu valley faced the similar fate. Hence, extensive studies are necessary to understand, model and predict the characteristic behavior of prevailing winds before we could think of developing wind power in the complex terrain of Nepal.

Significant studies on meteorological flow characteristics over the Kali Gandaki Valley appears to begin with the exploration of diurnal wind system (Egger et al., 2000) followed by numerical simulation of diurnal wind characteristics with the application of mesoscale meteorological model MM5 (Zängl et al., 2001). They observed as well as numerically predicted very intense up valley winds of speed $15-20 \mathrm{~ms}^{-1}$ during the daytime. These studies also show that the deep upvalley inflow wind layer may exhibit the nature of supercritical flow. The up valley winds begin to decelerate in the late afternoon and vanish in the late evening. Interestingly, a weak drainage flow develops over the valley only in the late night and may continue until late morning. Furthermore, investigation of characteristics of atmospheric stratification over the valley was carried out from 7 February to 27 March 2001 (Egger et al., 2002). This exploration appears to reconfirm the basic features of the local flow characteristics over the valley. These findings suggest that the fundamental features of the local flows over the Kali Gandaki Valley's complex terrain can be numerically simulated with the applications of advanced mesoscale meteorological models.

The Solar and Wind Energy Resource Assessment Project implemented by Alternative Energy Promotion Center, Government of Nepal, has developed a $50 \mathrm{~m}$ above the ground (AGL) wind potential map at $5 \mathrm{~km}$ horizontal resolution for the whole country (SWERA, 2008). However, the wind resource map developed by SWERA project is considered to be rather coarse estimation and lacked rigorous validations of the findings. As a result, it could not help much to develop wind power in the country and hence the World Bank is currently funding a project to develop wind resource map of Nepal at $3 \mathrm{~km}$ horizontal grid resolution (ESMAP, 2014) using WRF modeling system. We believe that it was possible and would have been much better if the efforts were made to develop wind resource map at least at $1 \mathrm{~km}$ horizontal grid resolution. Present study explores the wind energy potential over Kali Gandaki Valley in and around the Jomsom area using the WRF modeling system demonstrating the possibility of developing wind resource map of Nepal at $1 \mathrm{~km}$ horizontal grid resolution over the complex terrain of Nepal Himalaya.

\section{METHODOLOGY}

The local flow characteristics over the Kali Gandaki valley were studied with the application of the state-of-the-art-of Weather Research and Forecasting (WRF) Modeling System (Skamarock et al., 2008). The model was initialized with NCEP 6-hourly meteorological data with a resolution of $1.0^{\circ} \times 1.0^{\circ}$. The simulation was carried out for the period of a month of winter, spring, summer and autumn seasons of the year 2012, that is, January, April, July and September, respectively. In this calculation we used land use of 24 categories and 30 -second terrain elevation data by United States Geological Survey (USGS). The domain system used in this calculation consists of a triply nested two-way interacting mesh. The coarse and the fine domain include $52 \times 52 \times 35$ grid points, and horizontal grid size is 9 and $3 \mathrm{~km}$, respectively, whereas the finest domain include $70 \times 70 \times 35$ grid points with horizontal grid size is $1 \mathrm{~km}$. The area coverage and terrain structure of the finest domain is shown in Figure 1. The center of the calculation was set close to the observation site $\left(28.86^{\circ} \mathrm{N}\right.$ and $\left.83.78^{\circ} \mathrm{E}\right)$ few kilometers upstream to the Jomsom Airport (see Figure 2 for domain configurations and locations). The simulations were carried out using YSU Planetary Boundary Layer scheme (Hong et al., 2006), and surface layer schemes and the NOAH land surface model (LSM), along the Dudhia short wave, RRTM long-wave radiation parameterizations. The parameterization of scheme Lin et al. and the Kain-Fritsch convective parameterization scheme were used for coarse domain whereas no such parameterization scheme is used for the fine and finest domains. The rationales of the model predictions were examined against the observed diurnal variation of temperature and wind speed. 


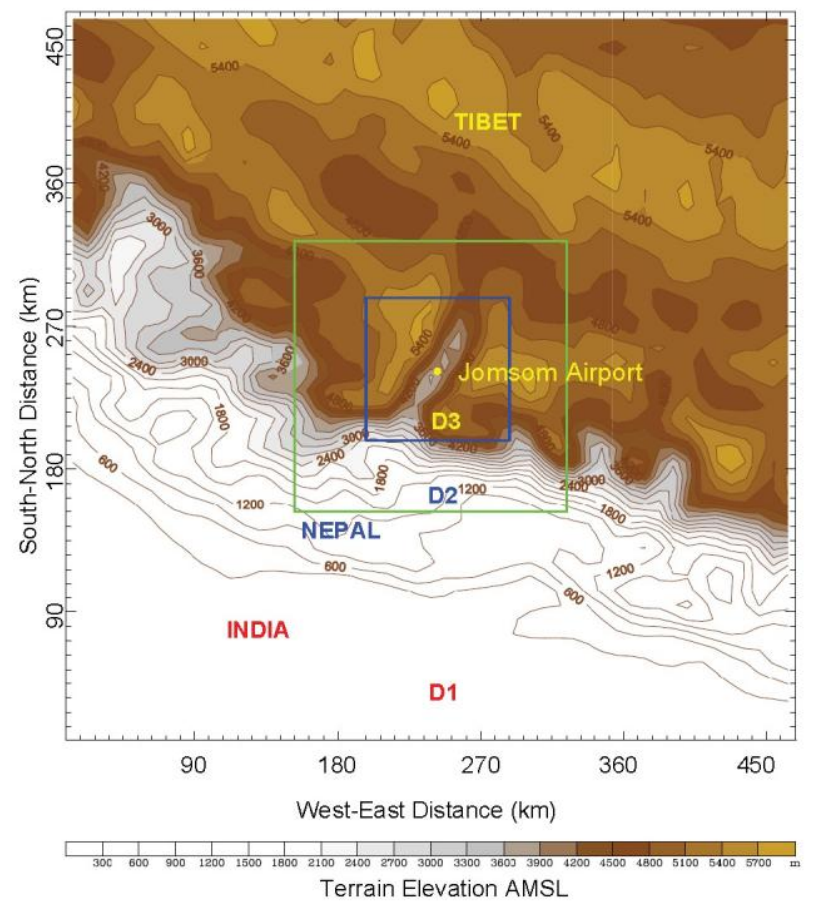

Fig.2. Geographical coverage of calculation domains: coarse domain (D1), fine domain (D2) and the finest domain (D3) of horizontal grid resolution 9,3 and $1 \mathrm{~km}$, respectively. The finest domain of $70 \mathrm{~km} \times 70 \mathrm{~km}$ area covers the whole Kali Gandaki Valley. The center of all the domains is set close to Jomsom Airport $\left(28.86^{\circ} \mathrm{N}, 83.78^{\circ} \mathrm{E}\right)$.

The mean wind power densities have been calculated at the horizontal grid resolution of $1 \mathrm{~km} \times 1 \mathrm{~km}$ over $70 \mathrm{~km} \times 70 \mathrm{~km}$ area without appreciating the land-use restrictions using the formulation

$$
P=\frac{1}{2} \rho v^{3} \quad \mathrm{Wm}^{-2}
$$

where, $\mathrm{P}$ is the power density in watt per square meter, $\rho$ and $v$ are the air density and the wind speed as calculated by the model, respectively.

\section{RESULTS}

The basic characteristics of the wind system over the Kali Gandaki Valley predicted in present calculation closely resembled with the observed and simulated characteristics (Zängl et al., 2001; Egger et al., 2000; Egger et al., 2002) for corresponding seasons. Furthermore, simulation well reproduced the observed characteristics of diurnal variation of wind speed, wind direction and temperature, though, for a very limited period of observation. Judging from the consistency that can be seen in between the earlier findings and the present simulation results and good correlation with the available observations, it can be said that basic characteristics of the prevailing wind over the Kali Gandaki River Valley have been well captured in the present simulation. Based on these assertions, wind power densities for different seasons taking the representative month of each season have been calculated and mapped.

\section{Comparison observed and simulation}

Lack of necessary observed data prevented us to make desired comparisons. Only the data of wind characteristics and temperature for the period of May 15 to 17 were available from the meteorological station at Tangbe about $6 \mathrm{~km}$ north to Kagbeni. As it can be seen in the Figure 3, the simulated wind speed, wind direction and temperature compare well with the observations. The little differences seen can be primarily attributed to the differences in the heights of observation and model calculation levels. Moreover, the terrain is so complex that averaged over the $1 \mathrm{~km}^{-2}$ simulations may not resolve the very local effect at the observation site. The maximum wind speed for three consecutive days was found to be about 16, 18 and $19 \mathrm{~ms}^{-1}$ respectively in between 1400 LST and 1500 LST in the afternoon and rest of the high wind varies in between $11 \mathrm{~ms}^{-1}$ to $15 \mathrm{~ms}^{-1}$.

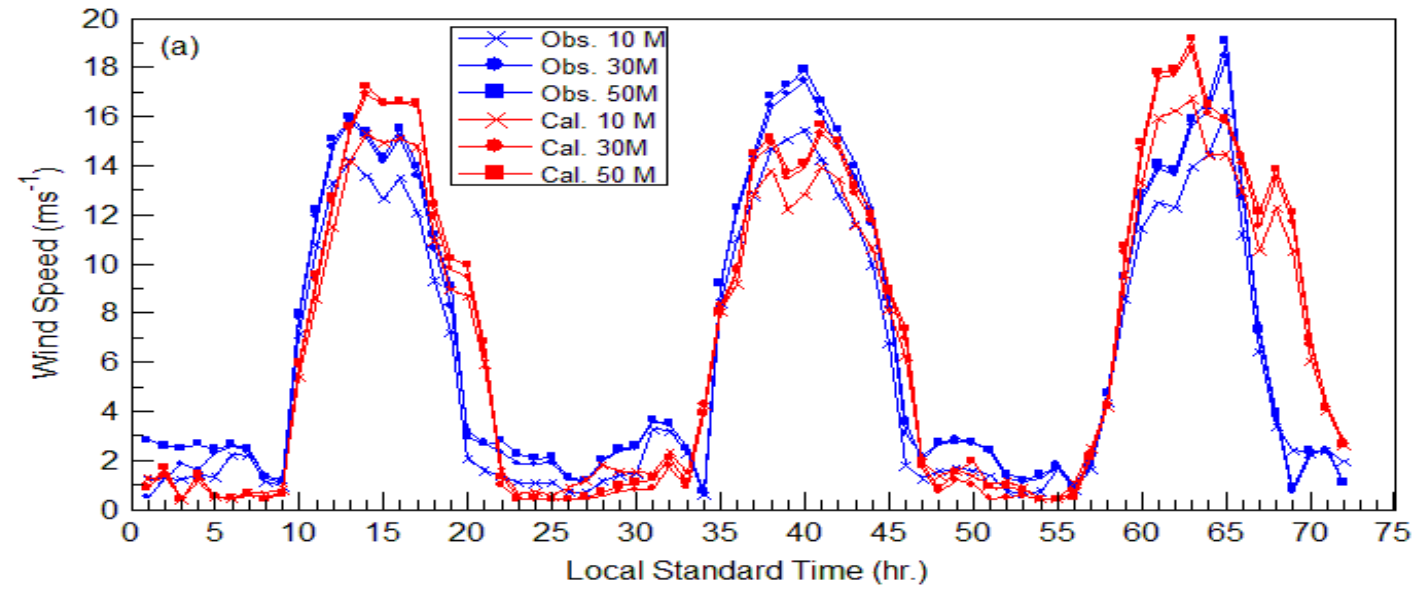



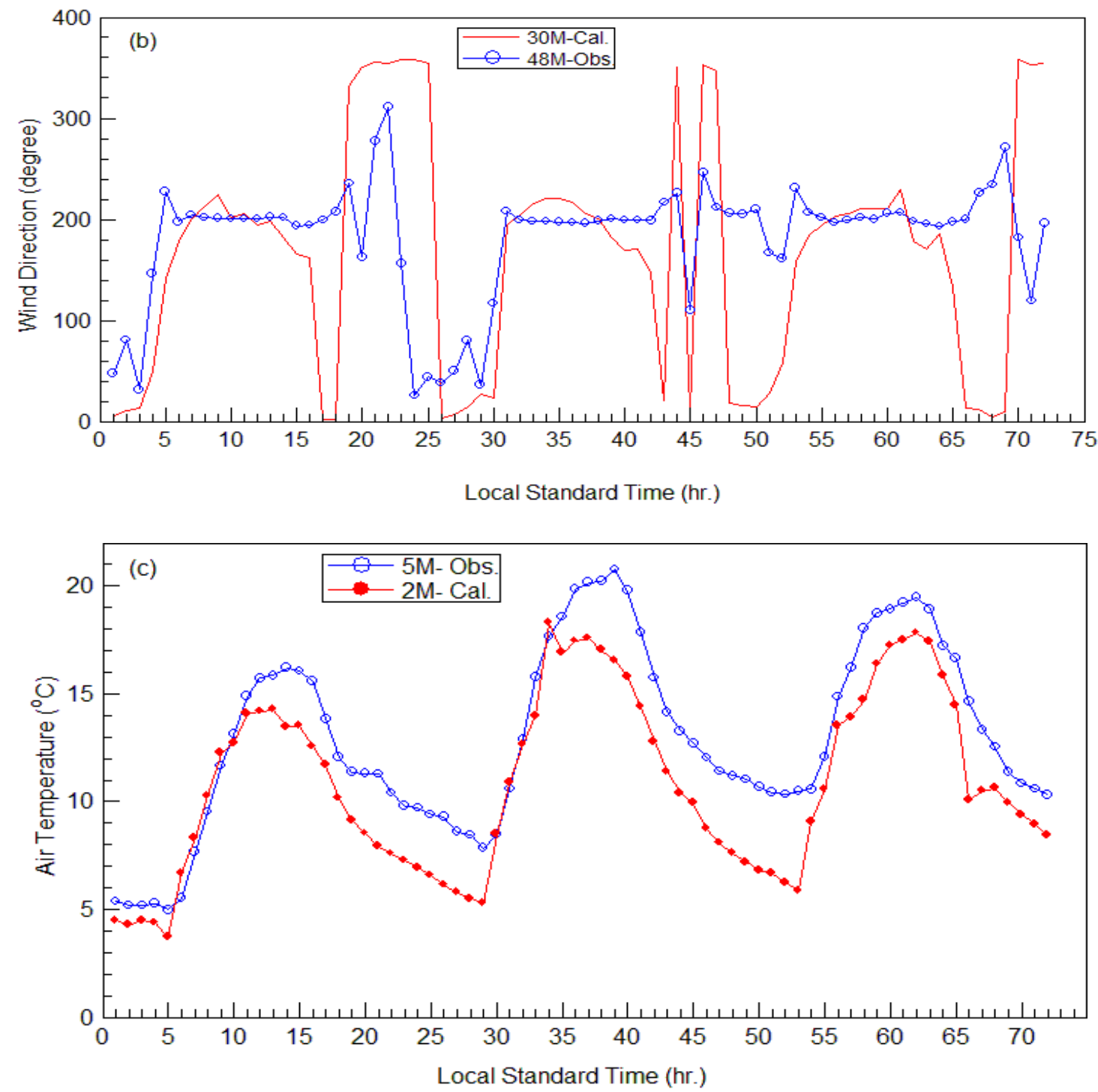

Fig. 3. Comparison of observed and the nearest grid point calculated wind speed (a), wind direction (b) and temperature (c). Time period begins from mid night of May 162012 and ends at mid night of May 182012.

\section{Distribution of wind power density}

Figure 4a-d show the wind power density distribution over the Kali Gandaki River Valley as calculated for the months of April, July, September and January 2012. Encouraged with the wind power potential seen in these months that may represent the scenarios of spring, summer, autumn and winter seasons, a long-term simulation at least for 5 consecutive years as well as the detailed field observation with sodar and automatic weather stations has been planned to carryout in the near future for the purpose of rigorous verification of present predictions.

As per the present limited time study, the Kali
Gandaki valley beginning from Tukuche up to Lo Manghan close to the exit point to the Plateau of Tibet, about $200 \mathrm{~km}^{-2}$ areas appear to possess good to excellent wind power potential at the height of 30 meters above the ground. Among the four months, April, July and the September (see Figure 4a-c), the Kali Gandaki Valley appears to possess more or less the same wind power density distribution pattern but its distribution appears to be significantly different for the month of January. Within the valley floor, the wind power density appears to be highest around the Jomsom-Kagbeni area and relatively higher around the Tukuche area compared to other parts of the valley floor area. 

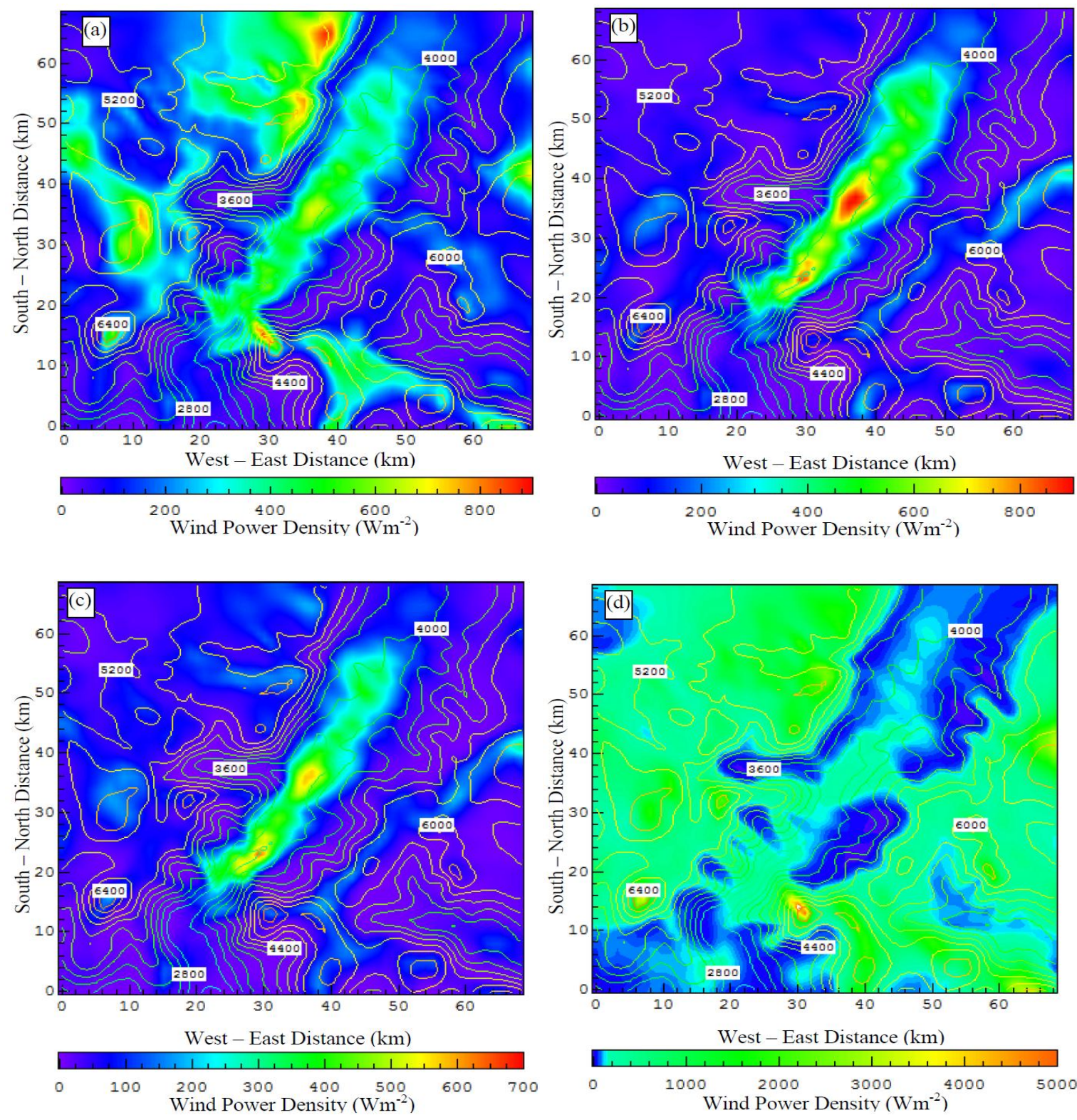

\section{Fig. 4. Wind power density distribution over the Kali Gandaki River Valley and its surrounding areas for the month of April (a), July (b), September (c) and January (d).}

These preliminary findings indicate that Kali Gandaki River Valley could be one of the most potential areas in Nepal to generate wind power. However, the nature of the wind appears to be rather adverse and asymmetric one, which cannot be overlooked. Firstly, the day time up valley wind appears to be supercritical and often show the signature of making hydraulic jump over the Jomsom-Kagbeni area and upstream during the afternoon and late afternoon time (not shown here). Perhaps, the Kagbeni wind farm in 1992 was hit by such supercritical flows that caused irreparable damages. Thus, it is very important to have a detail study of wind characteristics as well as intensive engineering examinations are necessary for the sustainability of the wind power project.

\section{CONCLUSIONS}

Preliminary assessment of prevailing wind power potential over the world's deepest river gorge with almost unparalleled topographic complexities has been made at $1 \mathrm{~km} \times 1 \mathrm{~km}$ horizontal grid resolution using the WRF modeling system for the January, April, July and September months of the year 2012. The simulation well reproduced the prevailing wind characteristics observed in the valley, although, 
only a few days data were available to compare. The wind power potential appears to vary from good to outstanding over $200 \mathrm{~km}^{2}$ area at 30 meters height above the ground with maximum potential around Jomsom-Kagbeni area of the valley. Based on the findings of earlier studies on the typical wind characteristics that may prevail over the valley, present findings of wind power potential distributions for months of January, April, July and September may represent the distribution of wind power potential over the valley for the winter, spring, summer and autumn seasons. However, detail long-term observations, numerical simulation as well as more engineering examinations are desired to derive definite conclusions on the true potential and sustainability of the wind power project in the area as the nature of the wind over the valley appears to be rather adverse and asymmetric one, which cannot be overlooked.

\section{ACKNOWLEDGEMENTS}

The University Grants Commission, Nepal and Central Department of Physics, Tribhuvan University, Kirtipur, Nepal are acknowledged for their generous support for this research. The Alternative Energy Promotion Center, Nepal Government is also acknowledged for sharing its observed three days diurnal data and Mr. A. Thapa for sharing the photograph of the first wind farm of Nepal.

\section{REFERENCES}

Chen, F., and Dudhia, J. (2001). Coupling an advanced land surface- hydrology model with the Penn State-NCAR MM5 modeling system. Part I: Model description and implementation. Monthly Weather Review, 129: $569-585$.

Dudhia, J. (1989). Numerical study of convection observed during the winter monsoon experiment using a mesoscale twodimensional model. J. Atmos. Sci., 46:3077-3107.
Egger, J.; Bajrachaya, S.; Egger, U.; Heinrich, R.; Reuder, J.; Shayka, P.; Wendt, H., and Wirth, V. (2002). Diurnal winds in the Himalayan Kali Gandaki Valley. Part III: Remotely piloted aircraft soundings. Monthly Weather Review, 130: 2042-2058.

Egger, J.; Bajrachaya, S.; Egger, U.; Heinrich, R.; Reuder, J.; Shayka, P.; Wendt, H., and Wirth, V. (2000). Diurnal winds in the Himalayan Kali Gandaki Valley. Part I: Observations. Monthly Weather Review, 128(4): 11061122.

ESMAP (2014). http://www.esmap.org/re_mapping nepal

Hong, S. Y.; Noh, S. Y.; Dudhia, J. (2006). A New Vertical Diffusion Package with an explicit Treatment of Entrainment Processes. Monthly Weather Review, 134:2318-2341.

Mlawer, E. J.; Taubman, S. J.; Brown, P. D.; Iacono, M. J., and Clough, S. A. (1997). Radiative transfer for inhomogeneous atmosphere: RRTM, a validated correlated-k model for the longwave. J. Geophys. Res., 102:16663-16682.

MOPE (2003). State of the Environment Nepal2003. Ministry of Population and Environment (MOPE), HMG Nepal. pp. 69.

Skamarock, W. C., et al. (2008). A description of the Advanced Research WRF version 3. NCAR Tech. Tep. TN-475+STR, pp. 113.

SWERA (2008). Solar and Wind Energy Resource Assessment in Nepal. Alternative Energy Promotion Centre, Government of Nepal. pp 13.

Zängl, G.; Egger, J., and Wirth, V. (2001). Diurnal winds in the Himalayan Kali Gandaki Valley, Part II: Modeling. Monthly Weather Review, 129: 1062-1078. 